IOS Press

\title{
Effect of two diurnal temperatures during simulated natural chilling of 'Gariguette' strawberry ${ }^{1}$
}

\author{
Jean-Philippe Bosc* \\ Ctifl Technical Centre for Fruits and Vegetables, Bellegarde, France
}

Received 23 October 2013; accepted 15 November 2013

\begin{abstract}
.
BACKGROUND: Chilling is traditionally assessed in France based on the number of hours below $7^{\circ} \mathrm{C}$.

OBJECTIVE: This research was carried out to evaluate the effect of two diurnal temperatures $\left(11^{\circ} \mathrm{C}, 16^{\circ} \mathrm{C}\right)$ with a night temperature below $7^{\circ} \mathrm{C}$ for chilling effect.

METHODS: 'Gariguette' cv. potted plants were grown with temperatures above $10^{\circ} \mathrm{C}$ in 2009 and above $14^{\circ} \mathrm{C}$ in 2010 until the onset of chilling conditions. Plants were transferred into controlled conditions during 68 days and exposed to $11^{\circ} \mathrm{C} / 2^{\circ} \mathrm{C}$ or $16^{\circ} \mathrm{C} / 2^{\circ} \mathrm{C}$ day/night temperatures, to differentiate four treatments: a) "mild" conditions $\left(16^{\circ} \mathrm{C} / 2^{\circ} \mathrm{C}\right.$ day/night $)$; b) "cold" conditions $\left(11^{\circ} \mathrm{C} / 2^{\circ} \mathrm{C}\right.$ day/night); c) "mild then cold" conditions (34 days each); d) "cold then mild" conditions (34 days each). Potted plants were then transferred to a heated plastic tunnel for fruit production assessment.

RESULTS: The "mild" treatment showed a lower fruit yield than the "cold" treatment. This negative effect of the "mild" treatment was compensated when plants were exposed to the "cold" treatment during half of the chilling duration ("cold then mild" or "mild then cold" treatment).

CONCLUSIONS: These results indicated that temperature fluctuations above $7^{\circ} \mathrm{C}$ have to be taken into account in case of a long chilling.
\end{abstract}

Keywords: Strawberry, chilling, dormancy

\section{Introduction}

In France, despite the increasing use of trayplants, the most common system to grow short-day strawberry cultivars is to plant frigo plants or potted plants in summer, in order to have a spring fruit production, particularly in soil productions. In southern France with Mediterranean climatic conditions, strawberry growers are aware that the early pickings are the most economically profitable with high selling prices. The early cultivar "Gariguette" (well-known by the French consumers) is widely cropped in these regions. The summer plantings are chilled by natural temperature conditions from November to January. As soon as the chilling requirements are fulfilled, forcing begins under closed or, for some soilless crops, heated plastic tunnels. The chilling assessment is traditionally based on the number of hours below $7^{\circ} \mathrm{C}$. Gariguette chilling requirements are considered to range between 700 and 900 hours below $7^{\circ} \mathrm{C}$ in this cropping system [1]. Various temperature bases are used in different countries to assess chilling, for instance $7^{\circ} \mathrm{C}$ in France, or $5^{\circ} \mathrm{C}$ in Japan [2]. Apparently, temperatures of $-2^{\circ} \mathrm{C},-1^{\circ} \mathrm{C}, 0^{\circ} \mathrm{C}$ and $3^{\circ} \mathrm{C}$ all chill effectively, $5^{\circ} \mathrm{C}$ and

\footnotetext{
${ }^{1}$ Paper presented at 2nd International Strawberry Congress, Hoogstraten, Belgium, Sept. 4-6, 2013.

*Corresponding author: Jean-Philippe Bosc, Ctifl Technical Centre for Fruits and Vegetables, 30127 Bellegarde, France. Tel.: +33 46601 10 54; Fax: +33 4660162 28; E-mail: bosc@ctifl.fr.
} 


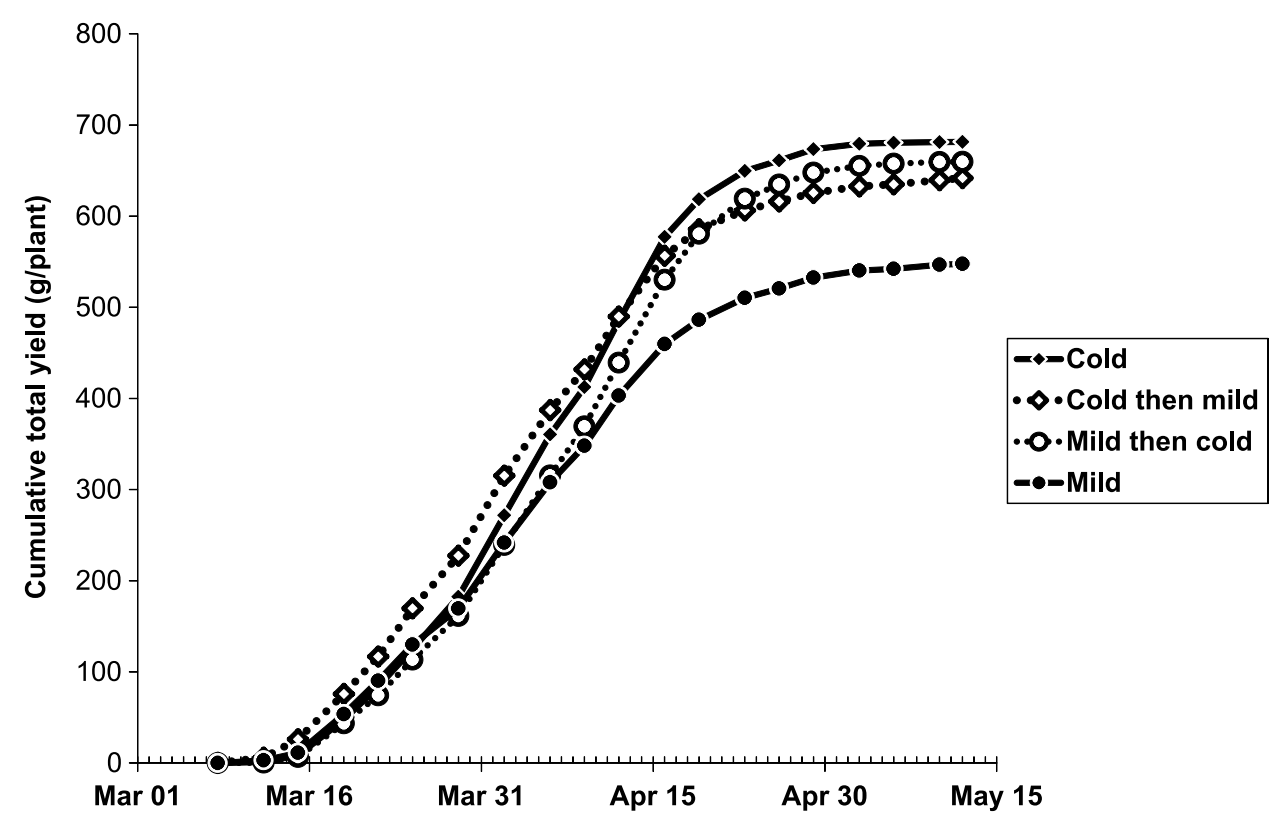

Fig. 1. 2010 - Evolution of cumulative marketable yield.

Table 1

2010 fruit production on May12th

\begin{tabular}{|c|c|c|c|c|}
\hline Treatment & Total yield (g/plant) & Marketable yield (g/plant) & $\begin{array}{l}\text { Average marketable } \\
\text { fruit weight (g/fruit) }\end{array}$ & Marketable fruit number/plant \\
\hline Cold & $682 a^{*}$ & $572 \mathrm{a}$ & 9.7 & $58.7 \mathrm{a}$ \\
\hline Cold then mild & $642 \mathrm{a}$ & $542 \mathrm{a}$ & 9.6 & $56.4 \mathrm{a}$ \\
\hline Mild then cold & $660 \mathrm{a}$ & $532 \mathrm{a}$ & 9.0 & $59.3 \mathrm{a}$ \\
\hline Mild & $548 b$ & $448 b$ & 9.0 & $49.8 b$ \\
\hline
\end{tabular}

${ }^{*}$ Means with no letters in common are significantly different (Newman-Keuls test, $5 \%$ level).

$6.5^{\circ} \mathrm{C}$ are almost as effective, $9.5^{\circ} \mathrm{C}$ and $10^{\circ} \mathrm{C}$ are less effective, and $14^{\circ} \mathrm{C}$ ineffective in breaking dormancy ([3-5]). Lieten [6] evaluated the chilling effect of different temperatures for "Elsanta" in the soilless Belgian cropping system, and found that $1.39^{\circ} \mathrm{C}$ was the most effective for fruit production, with a decreasing effect up to $12^{\circ} \mathrm{C}$, which has no chilling effect.

Due to sunny conditions during winter in the French Mediterranean areas, plants are subjected to various day and night temperatures during the chilling period. This research was carried out to evaluate the effect of two diurnal temperatures $\left(11^{\circ} \mathrm{C}, 16^{\circ} \mathrm{C}\right)$, with a $2^{\circ} \mathrm{C}$ night temperature to achieve chilling, on fruit production during the first production period.

\section{Material and methods}

Homogeneous potted plants of the "Gariguette" cultivar were planted in 3-litre pots, one plant per pot, on August 27th 2009 and September 20th 2010. They were grown at the Balandran Ctifl Centre (Southern France, Mediterranean conditions, $04^{\circ} 28^{\prime} \mathrm{E}-43^{\circ} 45^{\prime} \mathrm{N}$ ) under natural conditions in an outdoor nursery until October 13 th in 2009 and October 18 th in 2010 , and then in a heated tunnel (minimum temperature $10^{\circ} \mathrm{C}$ in $2009,14^{\circ} \mathrm{C}$ in 2010 ) to avoid chilling effect. Plants were fertilized daily with a complete fertilizing solution (EC $1.2 \mu \mathrm{S} \mathrm{cm}^{-1}$ ). The onset of chilling began 
Table 2

2011 fruit production on April 30th 2010 fruit production on May12th

\begin{tabular}{lcccc}
\hline Treatment & Total yield (g/plant) & Marketable yield (g/plant) & $\begin{array}{c}\text { Average marketable } \\
\text { fruit weight (g/fruit) }\end{array}$ & Marketable fruit number/ plant \\
\hline Cold & $543 \mathrm{a}^{*}$ & $512 \mathrm{a}$ & $12.6 \mathrm{a}$ & $40.6 \mathrm{a}$ \\
Cold then mild & $499 \mathrm{a}$ & $474 \mathrm{a}$ & $12.4 \mathrm{a}$ & $38.1 \mathrm{ab}$ \\
Mild then cold & $497 \mathrm{a}$ & $472 \mathrm{a}$ & $12.2 \mathrm{a}$ & $38.6 \mathrm{ab}$ \\
Mild & $411 \mathrm{~b}$ & $384 \mathrm{~b}$ & $11.3 \mathrm{~b}$ & $33.9 \mathrm{~b}$ \\
\hline
\end{tabular}

${ }^{*}$ Means with no letters in common are significantly different (Newman-Keuls test, $5 \%$ level).

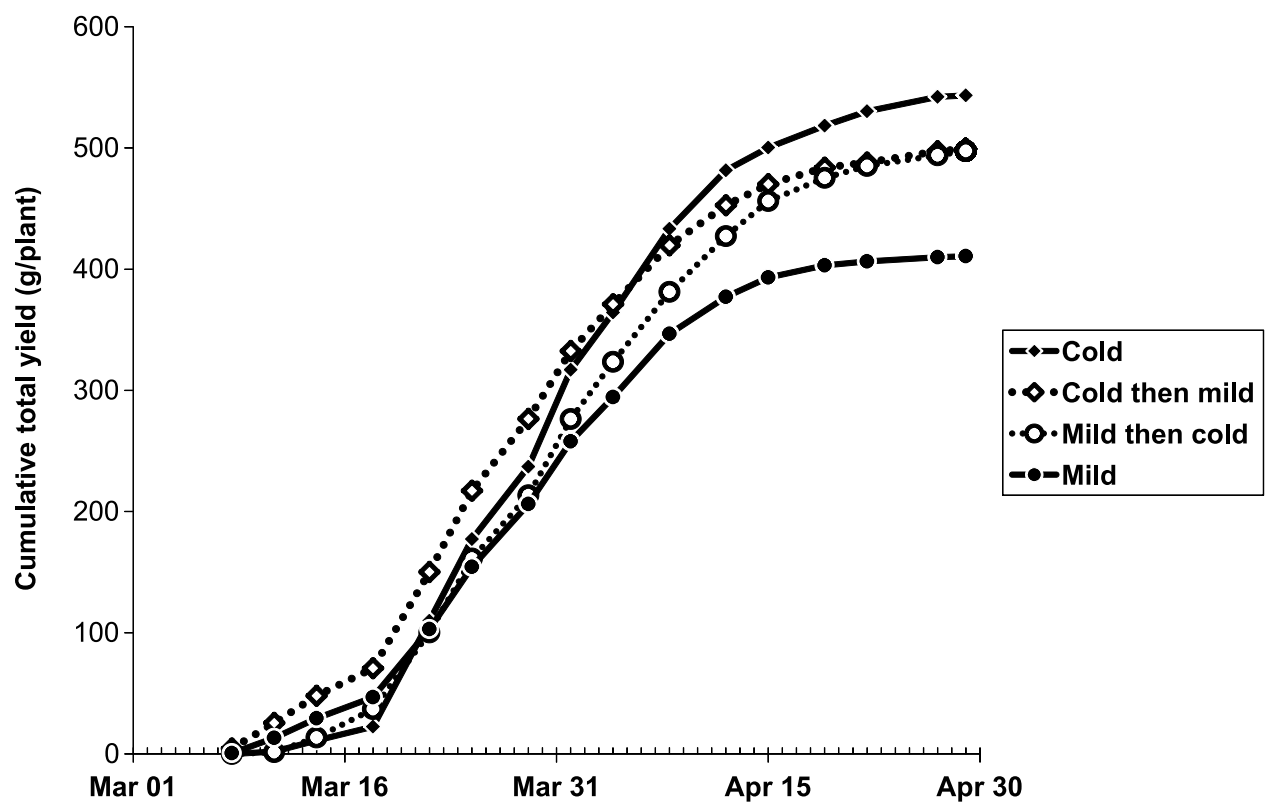

Fig. 2. 2011 - Evolution of cumulative marketable yield.

on18th November 2009, 17th November 2010, when plants were transferred into light and temperature controlled conditions in a climate room during 68 days and exposed to $11^{\circ} \mathrm{C} / 2^{\circ} \mathrm{C}$ or $16^{\circ} \mathrm{C} / 2^{\circ} \mathrm{C}$ day/night temperatures, with the same duration under $7^{\circ} \mathrm{C}$ ( 815 hours and 820 hours in 2009 , and $828 \mathrm{~h}$ and $830 \mathrm{~h}$ in $\left.2 \mathrm{O} 10\right)$. Four treatments were differentiated : a) "mild" conditions $\left(16^{\circ} \mathrm{C} / 2^{\circ} \mathrm{C}\right.$ day/night $)$ during 64 days; b) "cold" conditions $\left(11^{\circ} \mathrm{C} / 2^{\circ} \mathrm{C}\right.$ day/night) during 68 days; c) "mild then cold" conditions (34 days each); d) "cold then mild" conditions (34 days each). The four treatments had the same duration under $7^{\circ} \mathrm{C}: 815$ hours to 820 hours in 2010 , and $828 \mathrm{~h}$ to $830 \mathrm{~h}$ in 2011. A 10 h lighting was achieved with "coolwhite" fluorescent lamps (Sylvania T8 standard F58 W/133). Plants were watered without fertilization. On January 24th 2010 and January 25th 2011, plants were transferred to a heated plastic tunnel (minimum temperature $13^{\circ} \mathrm{C}$ ) and cropped as a classical forced soilless culture. Fruits were harvested twice a week for yield assessment during the first production period (May 12th in 2010 and April 29th in 2011).

\section{Results}

The 2010 and 2011 fruit productions showed some differences concerning final yield levels and characteristics. Fruit production curves: marketable yield lower in 2011 than in 2010, with a lower proportion of discarded fruits. Total production (marketable + discarded fruits) curves also exhibited some differences. 
Despite these differences, some common traits could be observed. "Mild" treatment exhibited a lower marketable yield for both years (Tables 1 and 2), with a lower fruit number in 2010 and 2011 and a lower marketable fruit weight in 2011. Marketable yield, fruit number, and fruit weight are not different for "Cold", "Cold then mild" and "Mild then cold" treatments in both years.

Fruit production curves revealed differences between the four treatments (Figs. 1 and 2). "Cold then mild" is the earliest for fruit production in both years: cumulative production is higher on March 25th or 29th in 2010 or on March 29th in 2011. In the same period, the "cold" treatment cumulative yield begins to differentiate from "mild then cold" and "mild" treatments" and is higher on April 6th or 9th in 2010 and on April 6th in 2011. "Mild then cold" treatment begins to differentiate later from the "cold" treatment and is statistically different on April 16th in 2010, and April 12th in 2011.

\section{Conclusions}

This two-year experiment, simulating a French Mediterranean winter, exhibited the effect of diurnal temperature during the chilling period for spring fruit production. A $16^{\circ} \mathrm{C}$ temperature during the day had a negative effect on first fruit yield in spring, compared to $11^{\circ} \mathrm{C}$ during the day for a 68 -day period of chilling at $2{ }^{\circ} \mathrm{C}$ during the night. The influence of a $16^{\circ} \mathrm{C}$ day temperature became more and more effective in the second half of the picking period. This negative influence is less effective if plants are exposed to a $11^{\circ} \mathrm{C}$ day temperature during the first 34 days or last 34 days of the 68-day chilling period. A day temperature of $11^{\circ} \mathrm{C}$ during the first 34 days enhanced fruit production earliness. A temperature of $11^{\circ} \mathrm{C}$ during the last 34 days of the chilling period only enhanced late fruit production. The experiment pointed out that, even if chilling requirements are supposed to be fulfilled with $800 \mathrm{~h}$ under $7^{\circ} \mathrm{C}$, side effects of an $11^{\circ} \mathrm{C}$ day temperature must be taken into account during long chilling periods with temperature fluctuations.

\section{References}

[1] Bigey J. Chilling requirements and compensation for the lack of chilling in strawberry. Acta Hort. 2002;567:269-72.

[2] Yanagi T, Oda Y. Effects of photoperiod and chilling on floral formation of intermediate types between June- and everbearing strawberries. Acta Hort. 1993;348:339-46.

[3] Takai T. Effective temperature for chilling and interaction of chilling and photoperiod on growth response of strawberry varieties. Bull Hort Res Stn, Series C (Morioka). 1970;6:91-101.

[4] Kronenberg HG, Wassenaar LM, Van de Lindeloof C PJ. Effect of temperature on dormancy in strawberry. Scientia Horticulturae. 1976;4:361-6.

[5] Risser G, Robert F. What cold treatments promote growth in strawberry? Acta Hort. 1993;348:381-3.

[6] Lieten P. Chilling unit model for greenhouse production of strawberry cv. 'Elsanta'. Acta Hort. 2006;708:381-7. 